IZA DP No. 4775

No Country for Fat Men? Obesity, Earnings, Skills, and Health among 450,000 Swedish Men

Petter Lundborg

Paul Nystedt

Dan-Olof Rooth

February 2010 


\title{
No Country for Fat Men? Obesity, Earnings, Skills, and Health among 450,000 Swedish Men
}

\author{
Petter Lundborg \\ Lund University, VU University Amsterdam, Tinbergen Institute, \\ Netspar, HEP, Centre for Economic Demography and IZA \\ Paul Nystedt \\ Linköping University and HEP \\ Dan-Olof Rooth \\ Linneaus University, Lund University, CReAM, \\ Centre for Economic Demography and IZA
}

\author{
Discussion Paper No. 4775 \\ February 2010
}

\author{
IZA \\ P.O. Box 7240 \\ 53072 Bonn \\ Germany \\ Phone: +49-228-3894-0 \\ Fax: +49-228-3894-180 \\ E-mail: iza@iza.org
}

\begin{abstract}
Any opinions expressed here are those of the author(s) and not those of IZA. Research published in this series may include views on policy, but the institute itself takes no institutional policy positions.

The Institute for the Study of Labor (IZA) in Bonn is a local and virtual international research center and a place of communication between science, politics and business. IZA is an independent nonprofit organization supported by Deutsche Post Foundation. The center is associated with the University of Bonn and offers a stimulating research environment through its international network, workshops and conferences, data service, project support, research visits and doctoral program. IZA engages in (i) original and internationally competitive research in all fields of labor economics, (ii) development of policy concepts, and (iii) dissemination of research results and concepts to the interested public.
\end{abstract}

IZA Discussion Papers often represent preliminary work and are circulated to encourage discussion. Citation of such a paper should account for its provisional character. A revised version may be available directly from the author. 
IZA Discussion Paper No. 4775

February 2010

\section{ABSTRACT \\ No Country for Fat Men? \\ Obesity, Earnings, Skills, and Health among 450,000 Swedish Men*}

The negative association between obesity and labor market outcomes has been widely documented, yet little is known about the mechanisms through which the association arises. Using rich and unique data on 450,000 Swedish men enlisting for the military, we find that the crude obesity penalty in earnings, which amounts to about 18 percent, is linked to supplyside characteristics that are associated with both earnings and obesity. In particular, we show that the penalty reflects negative associations between obesity, on the one hand, and cognitive skills, non-cognitive skills, and physical fitness, on the other. Our results suggest that employers use obesity as a marker for skill limitations in order to statistically discriminate.

JEL Classification: $\quad$ I10, J10, J70

Keywords: obesity, overweight, earnings, cognitive ability, non-cognitive ability, health, physical fitness

Corresponding author:

Petter Lundborg

Lund University

Department of Economics

Box 7082

SE-220 07 Lund

Sweden

E-mail: petter.lundborg@nek.lu.se

\footnotetext{
* We thank John Cawley, Andrew Clark, Fabrice Etile, Pierre-Yves Geoffard, John Komlos, Inas Rashad, and participants at the workshop on the Economics of Obesity at the Paris School of Economics, December 3-4, 2009. A research grant from the Centre for Economic Demography at Lund University is gratefully acknowledged.
} 


\section{Introduction}

There has been a dramatic increase in the prevalence of overweight and obesity in most Western Countries during the last couple of decades (WHO, 2000). According to the World Health Organization, there were about 1.6 billion overweight and 400 million obese adults in the world in 2005 and these figures are believed to increase to about 2.3 billion and 700 million, respectively, in 2015 (WHO, 2006). In the U.S., the country most associated with the increase in obesity, the share of obese individuals has increased from 15 percent in the late 1970s to 31 percent at the turn of the millennium (Cawley, 2004). Although starting at a lower level, Sweden, which is the country at focus in this study, is no exception and the share of obese individuals has risen from 5 to 10 percent during the same time span, while the share being classified as overweight has increased from a quarter to about a third (Kallings, 2002). ${ }^{1,2}$ A similar increase in weight has occurred among Swedish 18 year old male enlistees, for whom the share being overweight and obese has increased from 6 and 1 percent, respectively, in 1971, to 13 and 4 percent, respectively, in 1997 (Rasmussen et al., 2000). ${ }^{3}$

The rapid increase in overweight and obesity has raised major public health concerns, since evidence links overweight and obesity to serious health problems, such as cardiovascular disease, diabetes and some cancer forms, as well as to low fertility and fecundity (e.g. Dixon, 2010; Despres, 2006; Calle et al., 2003; Gregg et al, 2007; Norman and Clarke, 1998; Jokela et al., 2008; Sallmén et al., 2006).

Accompanying the world-wide increase in overweight and obesity, a growing body of literature analyzes the association between body weight and labor market outcomes, such as earnings, wages, and employment. Extensive evidence from the U.S. suggests that there is a substantial obesity penalty in wages for women, whereas the results for men are weaker and more mixed (see e.g. Averett and Korenman, 1996; Behrman and

\footnotetext{
${ }^{1}$ Body Mass Index (BMI) is calculated as the person's weight (in kilograms) divided by the square of his/her height (in meters). A person is classified as overweight if his BMI is between 25 and 30 and as obese if his BMI exceeds 30.

${ }^{2}$ See Brunello, Michaud and Sanz-de-Galdeano (2008) for the obesity share among other European countries.

${ }^{3}$ Swedish men who enlisted for the army during the time period 1984-1997 constitute the study population in this paper. The share of overweight and obese individuals in this data is 10 and 2 percent, respectively.
} 
Rosenzweig, 2001: Cawley, 2004; Conley and Glauber, 2006; Han et al. 2009). Studies on European data confirm this picture (e.g. Lundborg et al. 2006; Brunello and D’Hombres, 2007).

The estimated associations between obesity and earnings are economically significant. The results in Cawley (2004), for instance, suggest that a difference in weight of 2 standard deviations among white females is associated with a difference in wages of 9 percent, which is equivalent to the wage effect of 1.5 years of education or 3 years of work experience. Similar results are reported on European data, where obese women are found to earn 10 percent less on average than non-obese women (Lundborg et al. 2006). If the estimated gap represents a causal effect of obesity on wages, the ongoing obesity epidemic could well be expected to influence economic development and growth worldwide in a non-negligible manner.

While the magnitude of the association between obesity and wages for men is still uncertain, even less is known about the core mechanisms through which such an association arises. The obesity penalty may reflect pure taste-based discrimination, health-related absenteeism, wages affecting obesity ${ }^{4}$, or the influence of certain underlying personal labor supply side characteristics that are linked to both productivity and obesity. Rooth (2009) found strong indications of discrimination ${ }^{5}$ against obese workers by measuring employer callbacks on fictitious job applications to real jobs, where pictures of an obese or non-obese person were randomly assigned to similar applications. ${ }^{6}$ This type of field experiments guarantees that the researcher has the same information about the worker as the employer and any difference in callback between an obese and non-obese person must therefore result from the randomly assigned picture. Although providing strong evidence on discrimination, it is not possible to disentangle

\footnotetext{
${ }^{4}$ For instance through low-wage workers' consumption of cheap, fattening food.

${ }^{5}$ Although discriminating between people on the grounds of weight is lawful in Sweden, we still use the term discrimination instead of differential treatment to comply with the jargon in the economic discrimination theories being discussed.

${ }^{6}$ The callback rate was significantly lower (about seven percentage points) for the obese applicants, which is clearly indicative of the existence of discrimination already in the earliest stages of the hiring process.
} 
whether the result reflects taste-based discrimination or statistical discrimination. ${ }^{7}$ Improved knowledge on the underlying mechanisms would improve our understanding of why obese people often seem to earn less and could therefore be informative for policymakers evaluating various public health measures.

In this paper, we focus on obesity status among men prior to entering the labor market and show that the obesity penalty arises mainly from supply-side productive characteristics that are associated with both obesity and earnings. In particular, we build on recent evidence of a negative association between obesity, on the one hand, and cognitive skills, non-cognitive skills, and physical fitness, on the other. Our results show that the lower cognitive and non-cognitive skills of obese people explain a large part of the obesity earnings penalty of about 18 percent but that an even larger part is explained by the lower physical fitness that accompanies obesity. Accounting for both skills and fitness, we are able to explain virtually the entire obesity penalty. To the extent that obesity is a marker of skills and fitness, our results suggest that employers statistically discriminate against obese workers.

We base our analyses on a unique large-scale military enlistment data set covering 450,000 Swedish men that underwent mandatory enlistment at age 18 during the years 1984-1997. Since the data was collected during a period when enlistment was mandatory in Sweden, the data covers more or less all Swedish men that were about 18 during this period. In order to study the association between obesity and earnings, we have further linked this data set to tax authority register data on earnings and parental information. Important for our purposes, the enlistment data contains information on weight and height, physical fitness, and cognitive and non-cognitive test scores, which are all measured in advance of entrance to the labor market. We are also able to identify 145,000

\footnotetext{
${ }^{7}$ In relation to this, it is interesting to note that in a survey conducted by the largest newspaper in Sweden, nine out of ten managers believed that employment decisions do depend upon the applicant's obesity status (Dagens Nyheter 2003). A major reason for this belief was that obese applicants were expected to be less productive, highlighting the role of statistical discrimination against obese people in hiring decisions. Later, Agerström, Carlsson, and Rooth (2007) found similar results for Swedish managers using implicit attitude testing.
} 
siblings in the data, which we exploit in order to account for unobserved heterogeneity at the family-level.

The remainder of this article is organized as follows. In Section 2, we review the evidence for a negative association between obesity, on the one hand, and cognitive skills, non-cognitive skills, and physical fitness, on the other, and discuss possible reasons for these associations. In section 3, the data is described and Section 4 discusses our empirical method. Section 5 then presents the results and Section 6 concludes.

\section{Literature review}

\section{Skills and obesity}

Our paper is related to a recent literature that highlights the importance of cognitive and non-cognitive skills for labor market outcomes in the developed world (Cawley et al., 2001; Heckman et al., 2006; Heckman and Rubinstein, 2001; Thomas and Strauss, 1997). Recently, variations in such supply side characteristics have been found to explain important parts of the observed height premium in wages and earnings (Persico et al 2004; Case and Paxson 2008, Lundborg et al. 2009). Whether such characteristics also explain important parts of the obesity penalty has to our knowledge not been thoroughly investigated before.

From this perspective, it is interesting to note that there is a growing literature finding evidence of a negative association between obesity and cognitive ability. The association has been indicated very early in the life span, i.e. among 2-3 years old children, controlling for a wide range of child, parent, and family characteristics (Cawley and Spiess 2008). Several different biological and socially orientated explanations for the association between obesity and cognitive skills have been proposed. Some researchers believe that overweight and obesity may cause physiologic brain changes that could impair general cognitive function or performance in some cognitive areas (Gustafson et al. 2003; Gustafson 2004). ${ }^{8}$ Another explanation is that obesity leads to less skill acquisition due to discrimination by teachers or classmates or because of obesity-related illness episodes. Yet other explanations focus on common genetic, environmental, or

\footnotetext{
${ }^{8}$ According to the cited studies, this may happen through subclinical inflammatory changes, vascular changes, or dysmyelinization of white matter.
} 
biologic factors that could play a role in the development of both cognitive ability and overweight and obesity. Poor early life conditions and/or parental background may for instance affect both subsequent body size as well as cognitive skills.

While there is no consensus in the literature on the mechanisms underlying the negative association between skills and obesity, it is interesting to note that the association appears very early in life, before school entry. This suggests that the association is not purely driven by discrimination of obese children by teachers or classmates, even though some evidence for this exists as well (see e.g. Puhl and Latner 2006).

Irrespective of the exact mechanisms underlying the relationship between obesity and cognitive skills, a prospective employer may use obesity as a marker for cognitive ability. For the employer, it matters less if obesity causally affects cognitive ability, if it is the other way around, or if both are driven by some third underlying variable, such as genetics or family background. In any case, the employer may use obesity to statistically discriminate. Thus, from the perspective of improving the understanding of labour market discrimination against obese people, the exact mechanisms behind the association between obesity and cognitive ability is of less concern. Instead, we simply note that given the negative relationship between obesity and cognitive skills, a reasonable hypothesis is that part of the obesity earnings penalty may reflect the lower cognitive ability that follow with obesity.

Besides cognitive ability, the recent labor economics literature has paid growing attention to the role of so called non-cognitive skills. In the literature, these type of skills essentially describes a range of personal characteristics potentially affecting productivity, but distinct from cognitive skills, such as motivation, self-confidence, sociability (the capability of interacting and working with others), persistence, time preference (the ability or will to postpone instant pleasures in favor of future returns), and charm. It is uncontroversial to presume that non-cognitive abilities are valued by employers, coworkers and potential customers in almost any kind of occupation. Indeed, this is what a recent body of research has shown, linking non-cognitive skills to various socioeconomic outcomes (see e.g. Heckman and Rubinstein 2001; Heckman et al 2006). In fact, some studies suggest that non-cognitive skills are at least as important as 
cognitive skill in determining earnings and employment (Heckman 2008; Heckman et al. 2006; Borghans et al. 2008).

A recent literature has also linked non-cognitive skills to overweight and obesity. This relationship has been relatively less attributed to biological processes and more to social processes. ${ }^{9}$ For instance, if overweight and obese people are excluded from non-cognitive skill building relations, activities and environments, there is a clear connection between obesity and this type of skills.

Evidence in Cawley and Spiess (2008) provides evidence of a link between obesity and social skills as early as ages 2-3. According to the authors, there are several underlying mechanisms by which this finding could be explained. It may be that children who lack social skills get fewer friends and therefore play less, which increases the risk of obesity. Alternatively, children who are stigmatized for their obesity do not get the opportunities to develop their social skills. Well in line with this reasoning, Cramer and Steinwert (1998) found that obese children are viewed as less desirable playmates among 3 year olds. Similar mechanisms may obviously be at work at older ages when it comes to relations with e.g. partners, employers, customers, and coworkers.

In a parallel vein of research, Persico et al. (2004) found that teen height explains a large part of the height premium in earnings, and that the premium is reduced when controlling for participation in high school sports and clubs. This caused them to conclude that participation in such activities shapes non-cognitive skills. If this is true, it does not seem farfetched to suggest that obesity, presumably being connected to low levels of participation in sports and related activities, may also be related to low accumulation of non-cognitive skills.

There is thus substantial evidence linking non-cognitive skills to both socio-economic outcomes and obesity. Given these associations, it is straightforward to formulate a hypothesis where part of the obesity penalty in earnings is reflecting the lower noncognitive skills of obese people, in a similar vein as with cognitive skills.

\footnotetext{
${ }^{9}$ An exception is Cortese et al. (2008), who argue that poor control of neural centers that are related to traits such as impulsivity and addictive tendencies could damage the control of food intake, possibly leading to overeating and subsequent overweight and obesity.
} 


\section{Obesity, physical fitness, and health}

Besides mental skills, i.e. cognitive and non-cognitive skills, obese people may also differ from non-obese people regarding physical skills. It is well known that obese people in general are less physically fit and less healthy than non-obese people. For instance, obesity increases the risk of coronary heart disease (Willett, 1995), type 2 diabetes (Colditz,1995), stroke and some types of cancer (Michaud, 2001). At the same time, there are several reasons to believe that physical fitness and health are rewarded traits on the labor market. Firstly, people in good physical shape may be more productive at work, work longer hours, and may be less on sick-leave. Such arguments are consistent with findings that link physical fitness, often measured through cardiorespiratory fitness (see the data section for a discussion), to a diminished risk of coronary artery disease, myocardial infarction, and all-cause mortality (see e.g. Metter et al. 2002; Gale et al. 2007; Wijndaele et al. 2007; Rowland, 2007). ${ }^{10}$ Employers may thus use obesity as a marker of long-run health and productivity in order to statistically discriminate. In line with this, numerous studies have documented a link between health and labor market outcomes, which is also suggestive of a positive association between physical fitness and labor market outcomes (see e.g Currie and Madrian 1999 for an overview).

Secondly, physical fitness may signal other traits that are valued on the labor market. Cardiovascular fitness, for instance, requires regular physical activity and a balanced diet and may hence be associated with personality traits, such as self-control, temperance, planning capabilities, endurance and patience, etc., thus coinciding with certain dimensions of non-cognitive skills. It should also be noted that there is a small but growing literature showing that individuals being engaged in leisure sport activities receive higher wages (see e.g. Lechner 2009 and the references therein, and Rooth 2010).

\footnotetext{
${ }^{10}$ It is not fully known why the body's capacity to transport oxygen to exercising muscles should have a positive effect on a range of health outcomes [US Department of Health and Human Services, 1996]. It has been hypothesized that the influence of cardiorespiratory fitness may be a direct one, through enhanced peripheral vascular reactivity or myocardial vascularisation, inhibition of thrombosis, or reduced risk of arrhythmias with higher cardiorespiratory fitness mitigating the effects of atherosclerotic vascular disease. An alternative hypothesis is that an expanded cardiovascular system and improved oxygen delivery may depress risk factors for cardiovascular disease. Yet an alternative hypothesis is that both cardiorespiratory fitness and health are affected independently by some third factor, such as genes or family environment.
} 
To sum up, there is extensive evidence linking obesity to cognitive skills, noncognitive skills, and physical fitness, and health. The same set of traits has been shown to be important determinants of labor market outcomes in a large number of studies. In our empirical analyses, we will therefore consider to what extent the observed obesity earnings penalty is explained by these respective types of traits.

\section{Data and descriptive statistics}

Our empirical analysis is based on a data set constructed by integrating registers from Statistics Sweden (SCB) and the Swedish National Service Administration. The latter contains information on every individual living in Sweden in the year 1999 who enlisted for the military between 1984 and $1997 .{ }^{11}$ Our study population consists of all males who were 28-38 years old in 2003, who enlisted for the military, and for whom there is full information on relevant variables. Enlisting for the military is carried out during a twoday procedure and is mandatory for all male Swedish citizens the year they turn 18. Only persons with severe handicaps, institutionalized persons (both due to mental disorders or being in prison), or persons living abroad are exempted from enlisting. ${ }^{12}$ It should also be noted that a refusal to enlist results in fines, and eventually in imprisonment. In order to avoid any confounding influence of ethnic discrimination, we restrict our analyses to native Swedish males, i.e., those born in Sweden to Swedish-born parents. ${ }^{13}$ Given these restrictions, our study population covers about 92 percent of the total native male Swedish population in the relevant cohorts.

Our base sample consists of 468,312 individuals. Out of these, 96 percent had positive annual earnings in 2003, i.e., 448,702 individuals, which is the sample that we use in our analyses. Hence, there is very little attrition in the data and it more or less

\footnotetext{
${ }^{11}$ The individuals had to live in Sweden during 1999, since many important variables, e.g. the enlistment information and the family information, are collected for the 1999 population data.

${ }^{12}$ Since the persons in our sample enlisted during the years 1984-1997, and since earnings are followed up in 2003, this implies that we lose a small number of people due to death and emigration. There is no information available on why a particular individual did not enlist.

${ }^{13}$ Moreover, non-native ethnic groups have a much lower participation rate for enlisting since only about fifty percent (or less) are Swedish citizens, making selective participation an issue for these groups.
} 
covers the entire native born male Swedish population. In some parts of the analysis, we instead focus on variation between siblings, which reduces the sample being analyzed to 145,210 individuals. Since the enlistment variables are measured by military personnel, and earnings by tax authorities, our results are not influenced by any reporting bias, which often plagues survey data.

Our measure of annual earnings includes income from work, self-employed income and social insurance benefits such as sickness benefits, child allowance and parental benefits for the year 2003 and is taken from the tax records. A sensitivity analysis conducted in Section 4.2.2, where only income from work and self-employed income is included in the measure of earnings, shows that the inclusion of social insurance benefits does not affect our results.

Cognitive skills are measured using a test similar in style to the AFQT in the US. The test is called the Enlistment Battery 80 and includes four separate tests; Instructions, Synonyms, Metal Folding and Technical Comprehension. The separate scores of these tests are aggregated into a standard composite measure calculated by the military enlistment service, which we also use in the analyses. The measure ranges from 1 to $9 .^{14}$

Non-cognitive skills are measured through interviews carried out by certified psychologists employed by the Swedish army. The ultimate purpose of the interview is to evaluate the conscript's ability to perform military service and to function in a war situation. This is achieved through an assessment of the enlistee's psychological stability and endurance, capability of taking initiatives, responsibility, and social competence. The assessment results in a composite enlistment score of non-cognitive skills, ranging from 1 to 9, which we standardize and use in our analyses.

Though the original purpose of the non-cognitive skill measure used here is to evaluate peoples' suitability to serve in a war situation, it seems reasonable to assume that the character traits valued by the military psychologists (psychological stability and endurance, capability of taking initiatives, responsibility and social competence etc.) may also be appreciated and rewarded in the labor market. Indeed, this is what we find in the empirical analysis.

\footnotetext{
${ }^{14}$ The general intelligence factor, G, is the variable used in this study. For more information about the G factor, see Caroll (1993).
} 
Our main measure of physical fitness is cardiovascular fitness. This is measured as the maximum resistance attained in watts when riding on a stationary bike during a specific time period (around 5 minutes). ${ }^{15}$ The measure is often denoted as Maximum Working Capacity (MWC) and has been found to be an important predictor of mortality among healthy men (e.g. Sandvik et al. 1993). Note also that this measure is closely related to maximum oxygen consumption (VO2max), which has been labeled as the single best measure of cardiovascular capacity and maximal aerobic power (Hyde and Gengenbach 2007) ${ }^{16} \mathrm{~A}$ correlation of 0.9 between the two measures has been reported in the literature and it has therefore been concluded that MWC provides a suitable measure of cardiovascular capacity (Patton et al. 1982).

Since individual needs for energy vary with body size, our measure of maximum oxygen consumption is expressed relative to body weight. Evidence also suggests that obesity is not related to maximum oxygen consumption in absolute terms but have a strong effect on consumption per kg body weight, which is usually considered to be the best indicator of physical fitness. ${ }^{17}$ Physical strength is captured by the maximum pressure exerted squeezing a bar by the strongest hand. Measurement of handgrip strength is a valid indicator of, and commonly used to assess, overall muscle strength (e.g. Metter et al. 2002, Gale et al. 2007).

In order to construct our indicators of being underweight, normal weight, overweight, or obese, we use information on Body Mass Index (BMI, see also footnote 1). Generally, a BMI (for men) ranging between 25 and 30 is usually thought to reflect "overweight",

\footnotetext{
${ }^{15}$ In the cycle ergonometry test, the subject was instructed to maintain pedal cadence between 60 and 70 rpm. The test was initiated with 5 min of submaximal exercise at work rates of 75 to $175 \mathrm{~W}$, depending on expected fitness. The work rate was then continuously increased by $25 \mathrm{~W} / \mathrm{min}$ until volitional exhaustion. In the end, the final work rate (Wmax) was recorded. For more details on the test procedure, see Lundborg et al. (2009).

${ }^{16}$ Directly measuring maximum oxygen consumption is costly and time-consuming, meaning that indirect measures are often preferred when large numbers of people are being tested.

${ }^{17}$ In contrast, absolute maximum oxygen consumption was shown by Lundborg et al. (2009) to explain a large share of the observed height premium in earnings. In the case of height, there are physical reasons to expect an association between height and maximum oxygen consumption in absolute terms, see Lundborg et al. (2009).
} 
whereas men with BMIs exceeding 30 are considered to be "obese”. When it comes to "normal weight", the upper bound of 25 is commonly used whereas the definitions of the lower bound varies somewhat. Most previous studies on labour market outcomes define normal weight within the range 20-25, and low weight below 20, whereas the World Health Organization uses a lower bound of 18.5 for their "normal” weight definition (WHO 2006). In this study we employ the former definition yielding four BMI categories of low (<20), normal (20-25), over-weight (25-30), and obese $(>30)$.

It should be noted that there are no strong incentives to underperform deliberately at the enlistment tests. The reason is that, for our study sample, the results of the tests had no impact on the probability of doing military service or not, since almost all people that enlisted during our study period also completed military service. Instead, the test results merely influenced the individual's placement within the army, meaning that poorer results typically led to a less qualified and meriting placement. We will however perform some sensitivity tests in order to examine if suspiciously low scores on the tests have any impact on our results.

For some of the explanatory variables there is missing information. This is most common for parental education and income for which information is missing for at most 12-13 percent of the sample. When there is missing information in a variable for an individual, we have imputed the individual's data with the sample variable mean and created an additional binary variable indicator taking on the value one when information is missing and zero otherwise. The same procedure is followed for non-cognitive skill and the physical capacity enlistment variables. ${ }^{18}$

\section{*** Table 3.1 about here $* * *$}

\section{Descriptive statistics}

In Table 3.1 we show descriptive statistics on the key variables used in the empirical analysis, subdivided by BMI-class. The main picture that emerges is that men of normal weight on average earn more than overweight or obese men. The raw differences are

\footnotetext{
${ }^{18}$ For these last three variables less than 0.1 percent of the population has missing information.
} 
quite large and a normal-weight man earns about $21 \%$ more than an obese man. ${ }^{19}$ Overweight and obese men also fare worse when it comes to cognitive and non-cognitive skills and measures of cardiovascular fitness and muscular strength.

The bivariate associations between earnings in 2003, skills and cardiovascular fitness on the one hand and BMI (at age 18) on the other, for the full sample are illustrated in figures 1-5. The pattern of log earnings along the BMI distribution is inversely J-shaped, with earnings peaking at a BMI-level of 22, which is in the midst of our "normal weight" BMI range, and decreases thereafter (see Fig 1). Men with a BMI score of about 21-23 on average earn about 15-16\% more than people who are of very low weight (BMI of about 15-16) or just obese (BMI of about 30).

\section{*** Figure 1 about here ***}

The connection between cognitive skills and BMI follows a similar pattern but peaks at a lower BMI-level of 20 (see Fig 2). The inverse J-shape is in this case rather symmetrical around the peak BMI level of 20, i.e. men with BMI-levels 15 and 25 on average having similar cognitive skill test scores (of about 4.85-4-90), and obese men scoring lower (below 4.5). This could be contrasted to the association between earnings and BMI, where overweight men earn more and just obese men (BMI 30) earn about as much as people with very low weight (BMI: 15-16).

The relationship between non-cognitive skill and BMI is inversely U-shaped, this type of skill reaching its' maximum at normal weight BMI of about 22-23, mildly obese, and men of very low weight scoring similar test values (see fig 3).

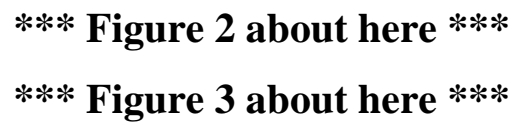

Turning to physical fitness, cardiovascular fitness is constant up to a BMI level of 21, but decreases rather linearly and steeply through the rest of the BMI span (fig 4).

\footnotetext{
${ }^{19}$ Mean logarithm earnings for men of normal and obese BMI are 12.35 and 12.16, respectively.
} 
Muscular strength is positively related to BMI up to a BMI level of about 25 (see fig 5). At higher BMI levels, muscular strength is rather constant.

Hence, in bivariate analyses, there is a connection between BMI and earnings, and also between BMI, on the one hand, and physical as well as cognitive and non-cognitive capabilities, on the other. In the empirical section, we will try to unravel whether, and to what extent, these capabilities may be associated with the observed obesity penalty in earnings.

\section{*** Figure 4 about here $* * *$ \\ *** Figure 5 about here $* * *$}

\section{Method}

In our empirical specification, we follow Neal and Johnson (1996) and only include variables determined in advance of entering the labor market. Controlling for factors like occupation, post-secondary education, and marital status may result in an underestimation of the obesity penalty, if part of it works through obese people sorting themselves into certain occupations, education levels or marital statuses. ${ }^{20}$ Our main earnings specifications therefore only include our measures of skills and physical capacity together with parental characteristics, such as education and earnings. Equation 1 shows the model being estimated for the total population data using ordinary least squares:

1) $\quad \ln y_{i}=a+b^{*} W_{i}+c^{*} X_{i}+d^{*} F_{i}+e_{i}$

where $\ln y_{i}$ denotes $\log$ earnings for individual $i, W_{i}$ is a vector of dummy variables indicating underweight, normal weight, overweight, and obesity, $X$ is a vector of controls for the individual characteristics measured when enlisting, and $F$ a vector of the parental characteristics. The model is altered by including different sets of variables into $X$. Our second specification controls for unobserved family and parental characteristics by estimating a sibling fixed effects model:

\footnotetext{
${ }^{20}$ A similar argument was put forth by Case and Paxson (2008), analysing the height premium in earnings.
} 
2) $\quad \ln y_{i j}=a+b W_{i j}+c^{*} X_{i j}+f_{j}+e_{i j}$

where $i j$ is an index for individual $i$ in family $j$ and $f_{j}$ represents family fixed effects capturing family characteristics common to all siblings within the same family, while $e_{i j}$ represent an individual specific error term. Identification of the coefficient $b$ thus relies upon sibling variation in BMI classification at age 18. In this specification, the estimate of $b$ should not be subject to any bias due to the influence of family-level unobservable factors.

In our OLS regressions, we control for age fixed effects, which picks up any nonlinearity in the age profile for earnings but also any changes in the measurement of the enlistment variables from year to year. Since 99 percent of the conscripts enlisted at age 18 or 19 (86 and 13 percent, respectively) the age fixed effects also pick up anything specific for the year the conscript enlisted. It is therefore reassuring that the results are insensitive to how we handle the age and age-when-enlisting variables, that is, including additional controls for age (fixed effects) when enlisting, or only including a control for linear age, does not change the results at all. 


\section{Results}

\subsection{Explaining the obesity penalty}

\subsubsection{Results for the total population data}

We start out with the full set of 448,667 observations, including only our BMI classification and age as explanatory variables into the earnings regression (Model A in Table 4.1). The results indicate that obesity is associated with an earnings penalty of 18.3 percent. The corresponding penalties for being overweight or underweight are 7.4 percent and 5.0 percent, respectively. The inclusion of height in the regression does not affect the results to any important extent (Model B). ${ }^{21}$ Controlling for parental characteristics in the form of education and earnings only slightly reduces the obesity penalty to 15.4 percent (see Model C). Hence, the estimated penalty does not originate from variations in parental characteristics, as manifested by the parents' education and income. ${ }^{22}$

The estimated raw obesity penalty of 18 percent is rather large. To put it into perspective, it could be noted that the estimated return to an additional year of schooling in Sweden is about 6 percent. The obesity penalty thus corresponds to three years of schooling, which corresponds to a university bachelor degree. While our estimated obesity penalty is larger than most previous estimates for males, one should keep in mind that we consider obesity at age 18, whereas most previous studies consider obesity at older ages. People who are obese already at 18 may be different from people who become obese at older ages. Moreover, for reasons explained in the method section, our estimate

\footnotetext{
${ }^{21}$ If being overweight or obese is associated with shorter stature, one would be worried that the omission of height would bias the coefficient of overweight or obesity downwards. The reason is that it is well established that height is positively associated with earnings (see e.g. Case and Paxson 2008 and Lundborg et al. 2009).

${ }^{22}$ As discussed in Section 3 we only include variables measured before labor market entry since sorting in the labor market could hide some of the weight penalties in earnings. Indeed this is what we find in that obese and overweight individuals are sorted into more low-paying occupations. Using 115 different occupational groups according to SSYK (Standard for Swedish Occupational Classification), a three digit occupational classification code similar to the international classification (ISCO), we find that the raw obesity/overweight penalty of eighteen and seven percent is reduced to seven and two percent, respectively, when measuring the average penalty within occupations. We also found evidence of sorting by (more) weight into (less) years of schooling, but to a much lesser degree (a penalty of twelve and four percent for obese and overweight, respectively). These results are available upon request.
} 
explicitly allow for sorting of obese people into certain educational tracks and occupations, where previous estimates often condition on such factors.

We next turn our attention to the supply side characteristics, where we expand Model C by including these characteristics one by one (Model D - G) and finally all of them together (Model H). The row denoted "Reduction (\%) in original (Model C) obesity penalty" contains information about how much the estimated obesity penalty is decreased in each Model D through H in comparison with Model C.

First, controlling for cognitive skills reduces the obesity penalty by one fifth, or from 15.3 percent to 12.2 percent (Model D). Cognitive skills are also clearly related to earnings, as a one standard deviation increase in the score is associated with 10.5 percent higher/lower earnings. Second, we control for non-cognitive skills, which more than halves the raw obesity penalty to 7.2 percent. Non-cognitive skills are in themselves an even more important predictors of earnings than cognitive skills and a one standard deviation increase in non-cognitive skills increases earnings with 13.3 percent (Model E). At the other end of the BMI-distribution, it is interesting to note that the earnings penalty for being underweight is practically eliminated when controlling for non-cognitive skills. Accounting for both cognitive and non-cognitive skills reduces the obesity penalty by $58 \%$ (not shown).

We then turn to our measures of physical fitness. Starting out with cardiovascular fitness, (Model F), it is evident that though this variable is less connected to earnings overall (a one standard deviation hereof increasing earnings by about 4.1 percent), it virtually wipes out the estimated obesity penalty (which is now only 0.1 percent). Muscular strength does not have a similar impact (Model G). Controlling for this type of capability actually slightly increases the obesity penalty to 16.2 percent.

In model $\mathrm{H}$, we then include all personal supply side characteristics (last column of table 3.1). Comparing the results with the previously estimated models, a notable feature is the relative similarity between the results for the obesity parameter values obtained in Model $\mathrm{H}$ and $\mathrm{F}$ (in which cardiovascular fitness was the only personal supply side characteristic included). The estimated obesity penalties in the two models are amounting to 2.7 percent and 0.1 percent respectively. It could also be noted that all the original BMI gradient parameters in earnings (model C) is reduced by more than 80 percent in 
accounting for the entire set of personal characteristics (model $\mathrm{H}$ ). Hence, four fifths of the observed obesity gradient in earnings could be predicted from supply side characteristics measured at age 18.

*** Table 4.1 ***

\subsubsection{Results for siblings}

The results presented so far do not take into account that, apart from parental earnings and education, there may be other unobserved family level factors governing the enlistees' future earnings, obesity and mental and physical skills. It seems likely that these traits, to some extent, are influenced by biological predispositions, social values, family traditions, and norms. Moreover, it is possible that some of the personal characteristics studied here are more associated with family background than others. To control for such family-specific effects, the models in the previous section was reestimated on the 145,193 brothers in the sample (see Table 4.2).

First, in order to examine whether our sibling sample is comparable to our main sample, we estimate the raw obesity penalty, without imposing sibling fixed effects. As shown in Model A in Table 4.2, the resulting estimate, 17 percent, is very similar to the corresponding gradient obtained for the full sample. Introducing sibling fixed effects, however, (see Model B in table 4.2) reduces the obesity penalty to 9 percent. This suggests that factors operating at the family-level explain almost half (47\%) of the raw obesity penalty in earnings.

As in the main sample, adding height (Model C) to the regression leaves the obesity premium unaltered. In model D, we then add cognitive skills, which reduce the obesity penalty by about one sixth to 7.6 percent. Whereas non-cognitive skill (Model E) has a similar impact on earnings (9.2 percent) as for the full sample, its inclusion now reduces the obesity penalty by more than 40 percent (to 5.2 percent). Accounting for both cognitive and non-cognitive skills gives a reduction in the obesity penalty of 46 percent. Model $\mathrm{F}$ then includes our measure of cardiovascular fitness, which again in essence eliminates the estimated overweight and obesity penalties, which now amounts to 0.1 percent and 0.2 percent, respectively. This implies that these penalties are reduced by about 98\% when cardiovascular fitness is controlled for. As in the full sample, muscular 
strength does not reduce the overweight and obesity penalties in earnings (model G). The full model $\mathrm{H}$ again renders the estimated penalties of underweight, overweight, and obesity insignificant. To summarize, the results obtained for the full sample are robust to the inclusion of family fixed effects. Next, in order to further check the robustness of our results, we turn to a number of different sensitivity analyses.

*** Table 4.2 ***

\subsection{Sensitivity analysis}

\subsubsection{Sensitivity analysis of the impact of different earnings definitions}

We start our sensitivity analyses by considering to what extent our results are sensitive to our measure of earnings. In particular, we examine whether or not the results are sensitive to the existence of extreme earnings, low earnings (below a 100' SEK), and the exclusion of sickness benefits. In these analyses, the sibling sample is used and a comparison is made to the obesity penalty estimated in Models $\mathrm{C}$ and $\mathrm{H}$ of Table 4.2. The results are presented in Table 4.3.

\section{*** Table 4.3 ***}

\section{Top coded earnings}

In the first column (i) of Table 4.3, the estimates from Table 4.2 (Model C and $\mathrm{H}$ ) are replicated. The second column (ii) then shows the corresponding estimates when annual earnings have been top coded to 500' SEK. $^{23}$ The BMI gradients in earnings resulting from this restriction are strikingly similar to the original ones, indicating that a skewed distribution of extremely high earnings towards people of normal weight is not driving the results of Section 4.2.

\footnotetext{
${ }^{23}$ This corresponds to about 50,000 Euros.
} 


\section{Hourly wage or hours worked?}

Annual earnings are the product of hours spent working during the year and the hourly wage rate. The structure of the data used here does not allow us to directly assess to what extent the estimated weight penalties in earnings is originating from variations in wage or hours of work. It has previously been shown by Antelius and Björklund (2000), however, that by excluding earnings below a threshold value of 100,000 SEK (approximately 10,000 euro) when analyzing annual earnings based on tax records in Sweden, one receives a return to education similar to the one obtained from analyzing hourly wages. Under the assumption that this result can be generalised to the present study, estimating the models including only those whose earnings are above 100,000 SEK should yield a weight penalty that more closely reflects the corresponding penalty in the wage rate. Under this presumption we conducted a sensitivity analysis excluding those with earnings below 100,000 SEK (12,312 individuals, or 8 percent, of the sample, see column (iii) of Table 4.5). This procedure indeed yielded weight penalties that are less pronounced. In model C, the exclusion of those with low earnings reduces the obesity penalty from 9.1 to 4.8 percent. This may indicate that part of the obesity penalty in earnings is due to larger fractions of obese men spending relatively fewer hours working or alternatively that the association between obesity and earnings is more pronounced for low earners. The latter interpretation is supported by results from (unconditional) quantile regressions on the total data, using only the weight indicators and age as regressors. The obesity penalty is $0.38,-0.26,-0.15,-0.12,-0.15,-0.20$, and -0.222 , respectively, for the 5th, 10th, 25th, Median, 75th, 90th and 95th percentiles. Hence, the penalty is greater at the top/bottom deciles, but quite stable in the interquartile range of the earnings distribution. The corresponding estimates for the overweight penalty are $-0.09,-0.09,-0.05,-0.05,-0.07$, 0.10 , and -0.11 , respectively. In model $\mathrm{H}$, the results do not change to any important extent when imposing the earnings restriction and the results are still insignificant.

\section{Earning subsidies}

As discussed above, obesity correlates with health. Hence, obesity-related differentials in earnings may to some extent capture variations in health and health related absenteeism from work. In the analyses in Section 4.1 and 4.2, we therefore used an earnings measure 
including sickness benefits, which, given the universality and relative generosity of the Swedish welfare system, mitigates some of the earnings differences that stems from sickness leave variations. In order to check the sensitivity of our results from the inclusion of sickness benefits, we re-ran our regressions with an earnings measure this time excluding subsidies, i.e. only including labour and/or self employed income. This implied that a smaller fraction of the population, 1,686 individuals, was excluded since their earnings consisted solely of such benefits. As shown in column (iv) of Table 4.3, the exclusion of such subsidies only slightly inflated the raw obesity penalty in earnings, compared with column (i), from 9.1 percent to 11.1 percent. For the full model $(\mathrm{H})$ a similar pattern was found, exclusion of subsidies somewhat inflating the obesity penalty and reducing the other parts of the BMI gradient in earnings. Hence, no important changes in the results emerged from the exclusion/inclusion of sickness benefits.

\section{Enlistment "fakers"}

We next address the possibility that some people may underperform during the various enlistment tests. One reason may be that people believe that they will be able to escape from certain positions in the army by performing poorly on the tests. For instance, those scoring above average on the cognitive test were evaluated on leadership skills and therefore ran the risk (or chance) of serving more months in a leadership position. Hence, in order to minimize the risk of being appointed to a higher rank and longer duty, a strategy could be to deliberately score low on the cognitive test. Note however that performing poorly would not make it possible for the individual to skip military service and would only affect the positions reached with poorer test scores leading to less qualified positions. In that sense, the incentives to underperform are somewhat weak. If the propensity to underperform does vary with BMI, however, our results may be biased. Although we find this scenario somewhat unlikely, we checked the sensitivity of our results by excluding very low test scores. Thus, we excluded every enlistee scoring a 1 or a 2 on the cognitive test (14151 individuals or $10 \%$ of the original sibling sample), and re-ran our analysis. It should be stressed that the distribution of expected test scores do cover the full range of possible values (1-9) and it is not necessarily so that very low scores reflect deliberate underperformance. Compared with column (i), the results of 
column (v) for both model $\mathrm{C}$ and $\mathrm{H}$ indicates that whereas the earnings gap of those of low weight and overweight are basically unaltered, the obesity penalty is inflated somewhat, from 9.1 percent to 11.3 percent (Model C) and from 1.5 percent to 3.9 percent (model H).

\section{Misclassified individuals}

Using BMI in order to categorise people into obese, overweight, etc always means a risk that some people will get misclassified. Some people with a BMI above 25 may be classified as overweight, although their BMI rather reflects a large muscle mass. Such misclassifications could be assumed to lead to a downward bias in the estimated obesity and overweight penalties, since a large muscle mass is something that should not affect labour market outcomes in a negative manner, but rather then opposite. We addressed this by excluding individuals from our analysis with an unusually large muscle mass and more exactly those who had a measured handgrip strength one standard deviation above the average handgrip strength. As shown in column (vi) of Table 4.3, this did not change the estimated obesity penalty. Instead, the penalty for being overweight increased somewhat, which is what one would expect, since some previously misclassified persons with large muscle mass are now taken out.

\section{Do obese people face lower returns to schooling?}

Our results could still reflect indirect preference discrimination if obese people invest less in schooling due to perceived discrimination. In other words, if preference discrimination exists, obese people would face lower returns to schooling and thus face reduced incentives to invest in schooling. This can be investigated by studying whether or not the returns to schooling in fact are less for obese people. We therefore ran models with interactions between our BMI-classifications and years of schooling. The coefficient of the interaction between obesity and schooling was small and insignificant, however, in both the total sample and the sibling sample. ${ }^{24}$ We therefore do not believe that a smaller return to schooling for obese people is an important explanation for our findings.

\footnotetext{
${ }^{24}$ The estimate of the obesity*years of schooling interaction term is -0.003 (s.e. $=0.006$ ) using the total data, and -0.018 (s.e. $=0.012$ ) using only siblings.
} 
Summarizing, the sensitivity analyses of this section show that the results of Section 4.1 are quite robust. It is also indicated that part of the BMI gradient in total earnings may be due to less hours worked and to a higher wage penalty for low-earners.

\section{Summary and discussion}

By using large-scale register data, we present new evidence on the obesity earnings penalty. In particular, we show that the penalty arises mainly from supply-side characteristics that are associated with both earnings and obesity, such as cognitive skills, non-cognitive skills, and physical fitness. Among these characteristics, physical fitness explained the major part of the obesity penalty.

Our results are consistent with the idea that employers use obesity as a marker for demanded skills in order to statistically discriminate. Physical fitness, which is likely to be related to productivity, health, and demanded personality traits, will be signaled through obesity status and employers, who may not have anything against obese individuals per se, may therefore statistically discriminate against obese people. Similar reasoning applies to cognitive and non-cognitive skills. This may also explain the finding in Rooth (2009), where job applications that signaled obesity received a significantly lower callback rate. Although our results are consistent with statistical discrimination, it is obviously impossible to completely rule out taste-based discrimination as an explanation for the results. However, it should be noted that the traits that we find "explain" the obesity penalty are traits that are widely believed to be related to productivity.

Our results show that the "obesity epidemic" should clearly be of interest to economists interested in the determinants of labor market performance. We obtain a raw obesity earnings penalty of about 18 percent. To put this into perspective, the estimated Swedish gender earnings gap is 16 percent (Kumlin 2007) and the earnings gap for men born outside Europe 15 percent (le Grand and Szulkin, 2002). Moreover, the obesity penalty corresponds to about three years of additional schooling, equivalent to an ordinary university bachelor degree.

Since our results suggest that the negative association between obesity and earnings runs mainly through the former's association with physical fitness and skills, it is of 
importance to better understand the mechanisms through which obesity is associated with these factors. Our data do not allow us to address the causal arrows running between obesity and skills. However, on a speculative basis, it could be noted that technological change is believed to have made the populations of Western countries fatter, through lower price of caloric intake and increased "price" of caloric expenditure through more sedentary work tasks (Lakdawalla et al. 2005). ${ }^{25}$ To the best of our knowledge, there is no simultaneous technological change that would explain why some groups would also face declining cognitive skills and non-cognitive skills. This may provide an indication that the lower skills and physical fitness faced by obese people are actually caused by obesity, in which case the impact of obesity on overall productivity and growth may be substantial. An interesting route for further research is thus to analyze the extent to which obesity causes declines in skills and physical fitness.

\footnotetext{
${ }^{25}$ The "price" of caloric expenditure refers to the monetary costs and the time costs involved in getting rid of calories, through spending time at the gym and engaging in sport activities, for instance. In an industrial society, the individual in principle got "paid" to exercise at work, through physically demanding job tasks, whereas today's jobs are mostly sedentary. The price of expending calories has thus gone up, since the individual now has to pay, both in terms of time and money, in order to expend calories.
} 


\section{References:}

Agerström, J., Carlsson, R. and Rooth, D. (2007) "Ethnicity and Obesity - Evidence of Implicit Work Performance Stereotypes in Sweden”, IFAU WP 2007:20. Uppsala, IFAU.

Antelius, J. and Björklund, A. (2000) "How Reliable are Register Data for Studies of the Return on Schooling? An examination of Swedish Data", Scandinavian Journal of Educational Research, 44(4):341-355.

Averett, S. and Korenman, S. (1996) "The Economic Reality of The Beauty Myth”, Journal of Human Resources, 31(2):304-330.

Behrman, J. and Rosenzweig, M. (2001) “The Returns to Increasing Body Weight”, University of Pennsylvania WP 01-052. Philadelphia.

Borghans, L., Duckworth, A., Heckman J. and ter Weel B. (2008) "The Economics and Psychology of Personality Traits”, Journal of Human Resources, 43(4): 972-1059.

Brunello, G. and D'Hombres, B. (2007) “Does body weight affect wages? Evidence from Europe”, Economics and Human Biology, 5(1):1-19.

Brunello, G., Michaud, P. and Sanz-de-Galdeano, A. (2008) "The rise in obesity across the Atlantic: An economic perspective”, IZA Discussion Paper No. 3529. IZA, Bonn.

Calle, E., Rodriguez, C., Walker-Thurmond, K. and Thun, M. (2003) “Overweight, obesity and mortality from cancer in a prospectively studied cohort of U.S. adults”, New England Journal of Medicine, 348(17):1625-1638.

Carroll, J. (1993) Human cognitive abilities. A survey of factor-analytic studies. Cambridge: University Press.

Case, A. and Paxson, C. (2008) "Stature and status: Height, ability, and labor market outcomes”, Journal of Political Economy, 116(3):499-532.

Cawley, J. and Spiess, C. (2008) "Obesity and skill attainment in early childhood”, Economics and Human Biology, 6(3):388-397.

Cawley, J., Heckman, J. and Vytlacil, E. (2001) “Three observations on wages and measured cognitive ability”, Labour Economics, 8(4), 419-442.

Cawley, J. (2004) “The Impact of Obesity on Wages”, Journal of Human Resources, 39(2):451-474.

Colditz, G. (1995) "Weight Gain as a Risk Factor for Clinical Diabetes Mellitus in Women”, Annals of International Medicine, 122(7):481-486. 
Conley, D. and Glauber, R. (2006) "Gender, Body Mass, and Socioeconomic Status: New Evidence from the PSID”, Advances in Health Economics and Health Services Research, 17(x):253-275.

Cortese, S., Angriman, M. Maffeis C, et al. (2008) "Attention-deficit/ hyperactivity disorder (ADHD) and obesity: a systematic review of the literature", Critical Reviews in Food Science and Nutrition, 48(6): 524-537.

Cramer, P. and Steinwert, T. (1998) “Thin is good, fat is bad: how early does it begin?”, Journal of Applied Developmental Psychology, 19(3):429-451.

Currie, J. and Madrian, B. (1999) "Health, Health Insurance and the Labor Market” in Handbook of Labor Economics, 3C: 3309-3407, David Card and Orley Ashenfelter (eds.), Amsterdam: North Holland.

Dagens Nyheter (2003) “Företag nobbar överviktiga”, Dagens Nyheter, February 27, p. 11.

Despres, J. (2006) “Is visceral obesity the cause of the metabolic syndrome?”, Annals of Medicine, 38(1):52-63,

Dixon, J. (2010) “The effect of obesity on health outcomes", Molecular and Cellular Endocrinology, 316(2):104-108.

Gale, C., Martyn, C., Cooper, C. and Sayer, A. (2007) "Grip strength, body composition and mortality”, International Journal of epidemiology, 36(x):228-235.

Gregg, E., Cheng, Y., Narayan, K., et al. (2007) ”The relative contributions of different levels of overweight and obesity to the increased prevalence of diabetes in the United States: 1976-2004”, Preventive Medicine, 45(x):348-52.

Gustafson, D., Lissner, L., Bengtsson, C., et al. (2004) ”A 24-year follow-up of body mass index and cerebral atrophy”, Neurology, 63(10):1876-1881.

Gustafson, D., Rothenberg, E., Blennow, K., et al. (2003) “An 18-year follow-up of overweight and risk of Alzheimer disease”, Archives of Internal Medicine, 163(13):15241528.

Han, E., Norton, E. and Stearns, S. (2009) "Weight and wages: Fat versus lean paychecks”, Health Economics, 18(5):535-548.

Heckman, J. and Rubinstein, Y. (2001) "Importance of Noncognitive Skills: Lessons from the GED Testing Program”, American Economic Review, 91(2):145-149. 
Heckman, J., Stixrud, J. and Urzua, S. (2006) "The effects of cognitive and noncognitive abilities on labor market outcomes and social behavior”, Journal of Labor Economics, 24(3):411-482.

Heckman, J. (2008) “Schools, skills, and synapses”, Economic Inquiry, 46(3):289-324.

Hyde, T. and Gengenbach, M. (2007) Conservative Management of Sports Injuries. 2nd ed; Sudbury, Mass.: Jones \& Bartlett.

Jokela, M., Elovainio, M. and Kivima ki, M. (2008) "Lower fertility associated with obesity and underweight: The US National Longitudinal Survey of Youth”, American Journal of Clinical Nutrition, 88(4):886-893.

Kallings, L. (2002) “Åtgärder mot fetma”, Report 2002:6. Swedish National Institute of Public Health (www.fhi.se).

Kumlin, J. (2007) "The Sex Wage Gap in Japan and Sweden: The Role of Human Capital, Workplace Sex Composition, and Family Responsibility", European Sociological Review, 23(2):203-221.

Lakdawalla, D., Philipson, T. and Bhattacharya, J. (2005) "Welfare-enhancing technological change and the growth of obesity", American Economic Review, 95(2):253257.

Lechner, M. (2009) "Long-Run Labour Market Effects of Individual Sports Activities”, Journal of Health Economics, 28(4): 839-854.

le Grand, C. and Szulkin, R. (2002) "Permanent Disadvantage or Gradual Integration: Explaining the Immigrant-Native Earnings Gap in Sweden”, Labour, 16(1):37-64.

Lundborg, P., Bolin, K., Höjgård, S. and Lindgren, B. (2006) ”Obesity and Occupational Attainment among the 50+ of Europe.”. In (eds) Bolin, K., and Cawley J.. Advances in Health Economics and Health Services Research Vol 17: The Economics of Obesity. Amsterdam: Elsevier.

Lundborg, P., Nystedt, P., and Rooth, D. (2009) "The Height Premium in Earnings: The Role of Physical Capacity and Cognitive and Non-Cognitive Skills". IZA Discussion Paper No. 4266. IZA, Bonn.

Metter, E., Talbot, L., Schrager, M. and Conwit. R. (2002) "Skeletal muscle strength as a predictor of all-cause mortality in healthy men", Journals of Gerontology Series A, 57(x):B359-B365.

Michaud, D. (2001) "Physical Activity, Obesity, Height and the Risk of Pancreatic Cancer”, JAMA - Journal of the American Medical Association, 286(8):921-929. 
Neal, D. and Johnson, W. (1996) "The Role of Premarket Factors in Black-White Wage Differences”, Journal of Political Economy, 104(4):869-895.

Norman, R. and Clark, A. (1998) “Obesity and reproductive disorders: A review”, Reproduction, Fertility and Development, 10(1):55-63.

Patton, J., Vogel, J. and Mello, R. (1982) "Evaluation of a maximal predictive cycle ergometer test of aerobic power”, European Journal of Applied Physiology and Occupational Physiology, 49(1):131-140.

Persico, N., Postlewaite, A. and Silverman, D. (2004) “The Effect of Adolescent Experience on Labor Market Outcomes: The Case of Height”, Journal of Political Economy, 112(5):1019-1053.

Puhl, R. and Latner, J. (2006) "Stigma, obesity, and the health of the nation's children”, Psychological Bulletin, 133(4):557-580.

Rasmussen, F., Bohman, P., Tynelius, P. and Johansson, M. (2000) ”Fysisk aktivitet och övervikt i Stockholms län och riket under de sista decennierna: (Physical activity and overweight in Stockholm and the nation during the last decades), in Swedish. Report 2000:1, Epidemiologiska enheten, Samhällsmedicin. Stockholms läns landsting.

Rooth, D. (2009) “Obesity, Attractiveness and Differential Treatment in Hiring: a Field Experiment”, Journal of Human Resources. 44(3):710-735.

Rooth, D. (2010) "Work Out or Out of Work: The Labor Market Return to Physical Fitness and Leisure Sport Activities”, IZA Discussion Paper No. 4684. IZA, Bonn.

Rowland, T. (2007) “Evolution of Maximal Oxygen Uptake in Children”. In (eds.) Tomkinson, G. and Olds, T., Pediatric Fitness. Secular Trends and Geographic Variability. Basel: Karger.

Sallmén, M., Sandler, D., Hoppin, J., Blair, A. and Baird, D. (2006) "Reduced fertility among overweight and obese men”, Epidemiology, 17(5):520-523.

Sandvik, L., Erikssen, J., Thaulow, E., Erikssen, G., Mundal, R. and Rodahl, K. (1993) "Physical fitness as a predictor of mortality among healthy, middle-aged Norwegian men”, New England Journal of Medicine, 328(x):533-537.

Thomas, D. and Strauss, J. (1997) "Health and wages: evidence on men and women in urban Brazil”, Journal of Econometrics, 77(1):159-185.

U.S. Department of Health and Human Services (1996) "Physical Activity and Health: A Report of the Surgeon General Atlanta, GA”, U.S. Department of Health and Human Services, Centers for Disease Control and Prevention, National Center for Chronic Disease Prevention and Health Promotion. 
Wijndaele, K., Duvigneaud, N., Matton, L., Duquet, W., Thomis, M., Beunen, G., Lefevre, J. and Philippaerts, R. (2007) "Muscular strength, aerobic fitness, and metabolic syndrome risk in Flemish adults", Medicine and Science in Sports and Exercise, 39(2):233-240.

Willett, W. (1995) "Weight, Weight Change and Coronary Hearth Disease in Women”, JAMA - Journal of the American Medical Association, 273(6):461-465.

World Health Organization (2000) "Obesity: Preventing and managing the global epidemic”. Report of a WHO Consultation (WHO Technical Report Series 894). WHO, Geneva.

World Health Organization (2006). Obesity and Overweight (WHO Fact Sheet No. 311). http://www.who.int/mediacentre/factsheets/fs311/en/index.html (Accessed September 26, 2009). 


\section{Figures:}

Figure 1. (Log) Earnings and BMI. Total population.

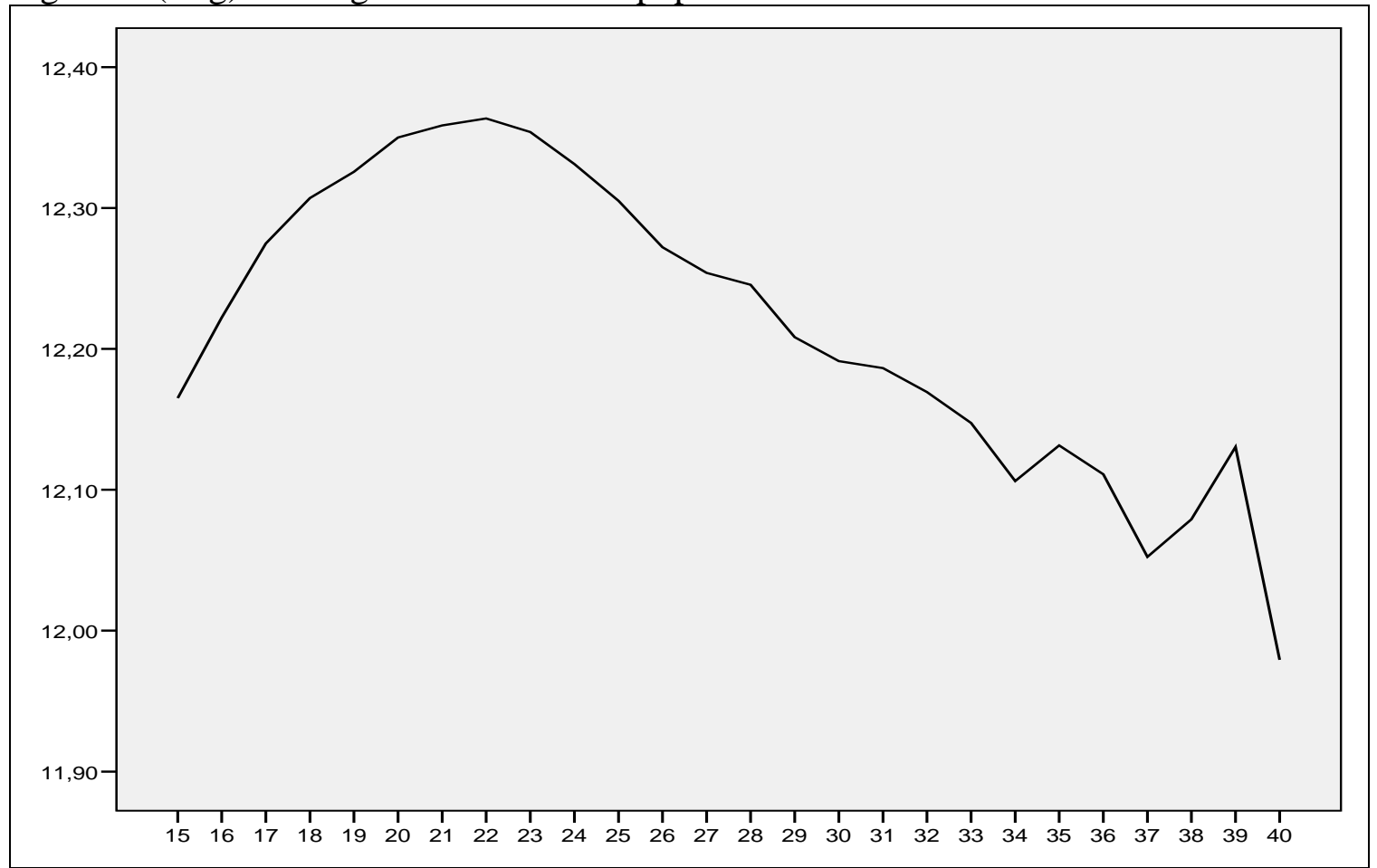

Note: The dependent variable is the mean for everyone with the integer value of the independent variable, being truncated at 15 and 40 . 
Figure 2. Cognitive skill and BMI. Total population.

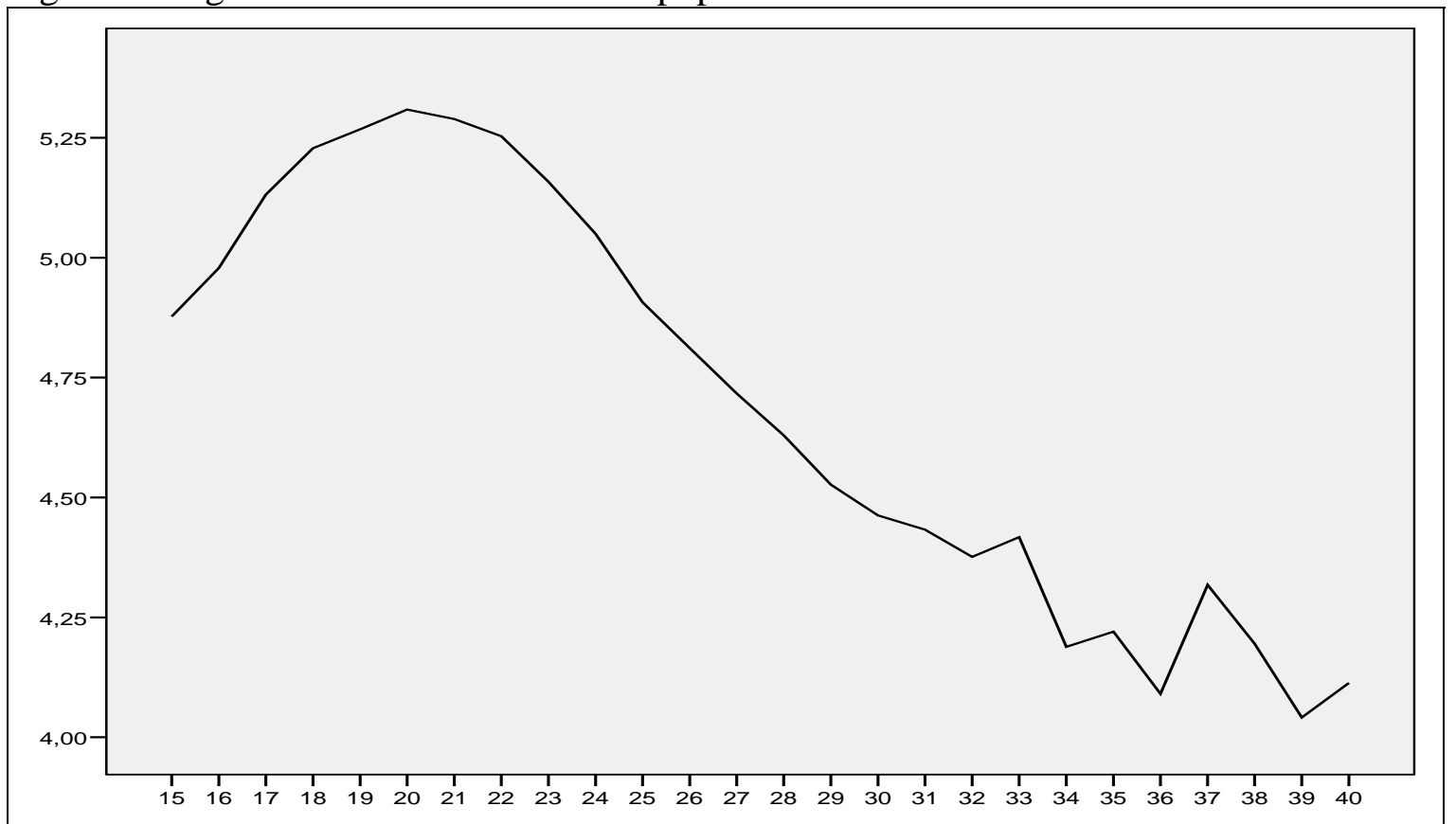

Note: The dependent variable is the mean for everyone with the integer value of the independent variable, being truncated at 15 and 40 . 
Figure 3. Non-cognitive skill and BMI. Total population.

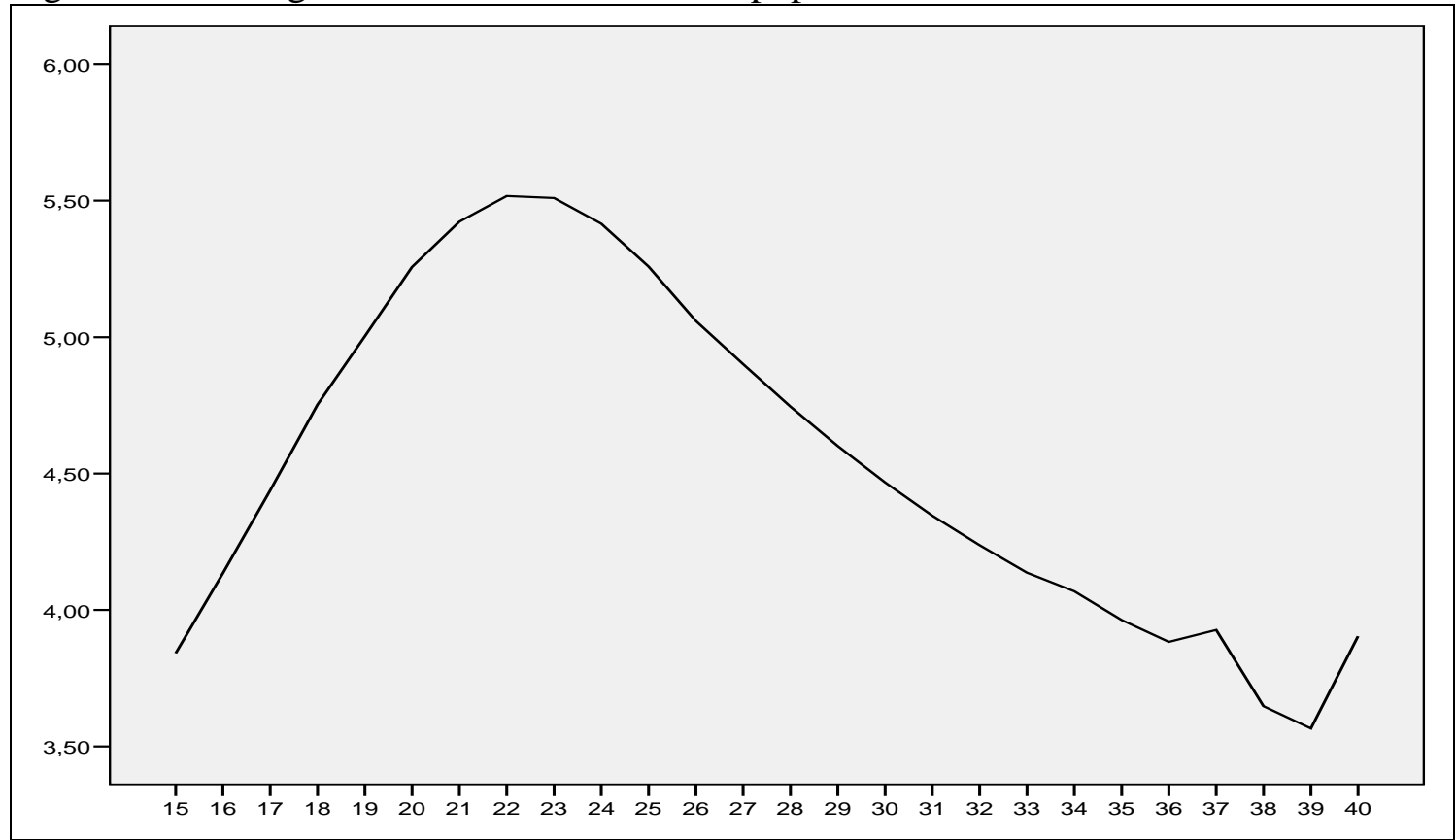

Note: The dependent variable is the mean for everyone with the integer value of the independent variable, being truncated at 15 and 40 . 
Figure 4. Physical fitness (wmax/weight in kg) and BMI. Total population.

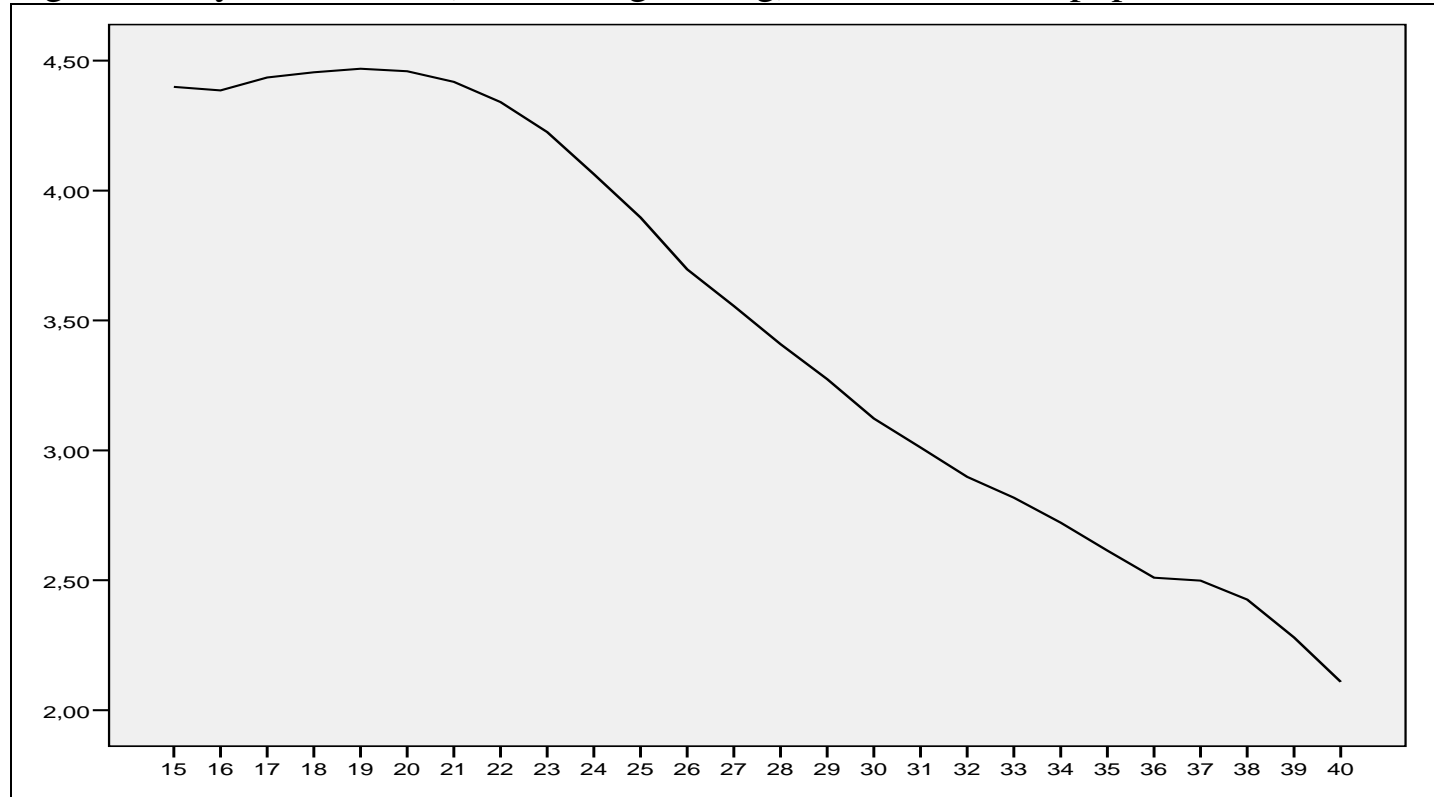

Note: The dependent variable is the mean for everyone with the integer value of the independent variable, being truncated at 15 and 40 . 
Figure 5. Handgrip strength and BMI. Total population.

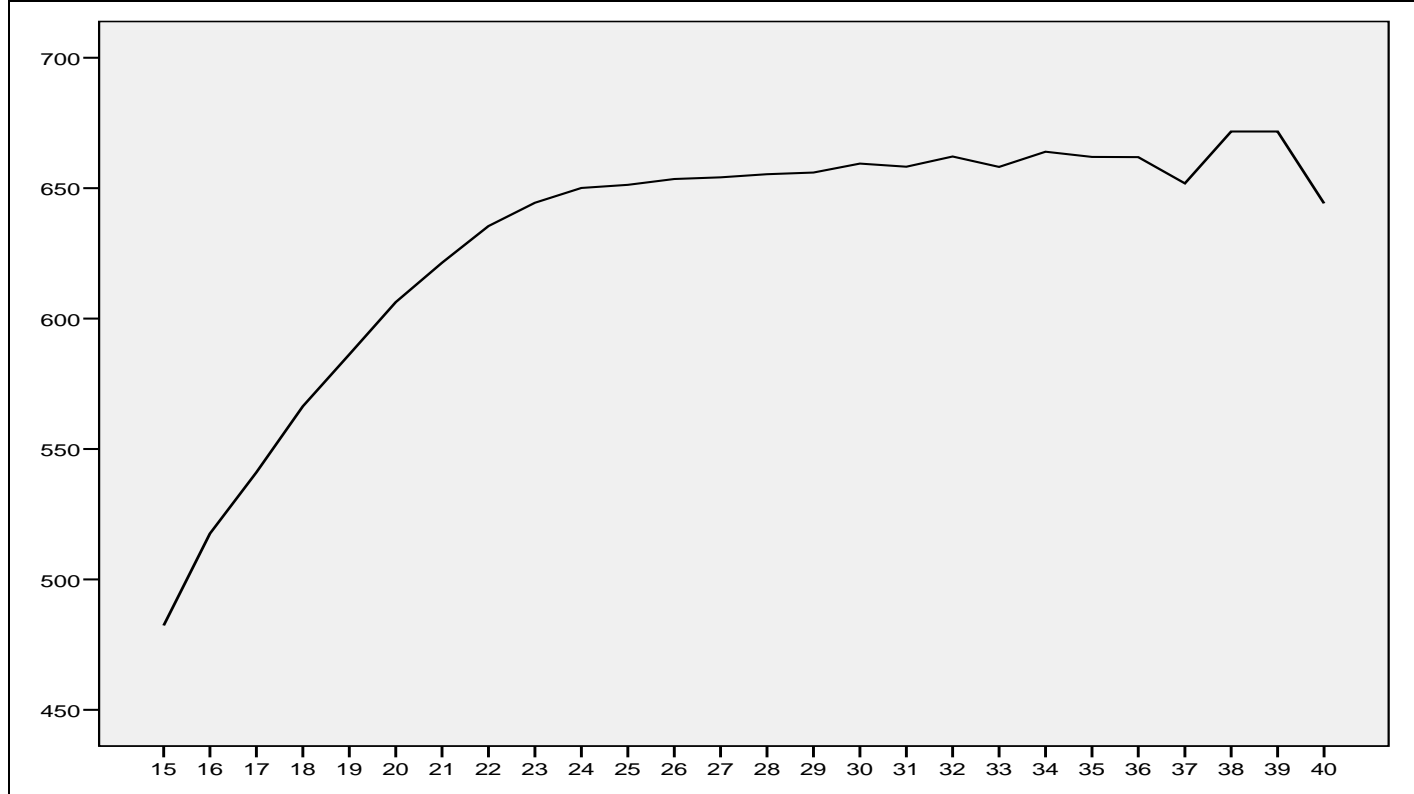

Note: The dependent variable is the mean for everyone with the integer value of the independent variable, being truncated at 15 and 40 . 


\section{Tables:}

Table 3.1. Descriptives of the population divided at BMI<20, 20<BMI<25, 25<BMI<30, and BMI $>30$. Men 28-38 years old, 2003. Total population.

\begin{tabular}{|c|c|c|c|c|c|c|c|c|}
\hline \multirow{2}{*}{$\begin{array}{l}\text { Variable } \\
\mathrm{BMI}\end{array}$} & \multicolumn{2}{|c|}{$<20$} & \multicolumn{2}{|c|}{$20-25$} & \multicolumn{2}{|c|}{$25-30$} & \multicolumn{2}{|c|}{$>30$} \\
\hline & 18.9 & $(0.9)$ & 22.0 & (1.3) & 26.7 & $(1.3)$ & 32.9 & (2.9) \\
\hline Logarithmannual earnings & 12.31 & $(0.81)$ & 12.35 & $(0.78)$ & 12.27 & $(0.78)$ & 12.16 & (0.84) \\
\hline Age & 33.3 & (3.1) & 33.1 & (3.2) & 32.9 & (3.2) & 32.6 & (3.2) \\
\hline \multicolumn{9}{|l|}{ Parental characteristics: } \\
\hline Fathers' (log) earnings & 11.07 & (0.50) & 11.07 & $(0.50)$ & 11.01 & (0.48) & 10.95 & $(0.46)$ \\
\hline Mothers' (log) earnings & 9.81 & (1.26) & 9.86 & (1.23) & 9.80 & $(1.25)$ & 9.76 & (1.27) \\
\hline Fathers years of schooling & 11.4 & (2.3) & 11.3 & (2.3) & 10.9 & $(2.0)$ & 10.6 & $(1.7)$ \\
\hline Mothers years of schooling & 11.4 & (2.2) & 11.4 & (22) & 11.0 & (2.0) & 10.6 & (1.8) \\
\hline Cognitive skill: & 5.2 & (2.0) & 5.2 & (1.9) & 4.8 & (1.9) & 4.4 & (1.9) \\
\hline \multicolumn{9}{|l|}{ Enlistment test score } \\
\hline Non-cognitive skill: & 4.8 & (1.5) & 5.4 & (1.6) & 5.0 & (1.6) & 4.2 & (1.5) \\
\hline \multicolumn{9}{|l|}{ Psychological evaluation } \\
\hline Physical fitness: & 4.46 & (0.68) & 4.35 & $(0.65)$ & 3.68 & (0.63) & 2.89 & $(0.56)$ \\
\hline \multicolumn{9}{|l|}{ Cardiovascular fitness } \\
\hline Muscular strength & 571.9 & (86.4) & 626.4 & (92.6) & 653.1 & $(101.7)$ & 659.6 & (108.4) \\
\hline Height & 179.8 & (6.6) & 179.5 & (6.4) & 179.2 & (6.5) & 179.4 & (6.7) \\
\hline No of observations & \multicolumn{2}{|c|}{110,859} & \multicolumn{2}{|c|}{285,913} & \multicolumn{2}{|c|}{43,117} & \multicolumn{2}{|c|}{8,778} \\
\hline
\end{tabular}

Notes: Standard deviations in parentheses. The variables on cognitive skill, non-cognitive skill and physical fitness are standardized when used in the empirical analysis. 
Table 4.1. Earnings and BMI. Men 28-38 years old, 2003. Logarithm of annual earnings. Total population data.

\begin{tabular}{|c|c|c|c|c|c|c|c|c|}
\hline Variable & A & $\mathrm{B}$ & C & $\mathrm{D}$ & $E$ & $\mathrm{~F}$ & $\mathrm{G}$ & $\mathrm{H}$ \\
\hline $\mathrm{BM} \leq 2 \mathrm{O}$ & $\begin{array}{l}-0.050^{\star \star \star} \\
(0.003)\end{array}$ & $\begin{array}{l}-0.052^{\star \star *} \\
(0.003)\end{array}$ & $\begin{array}{l}-0.052^{\star \star \star} \\
(0.003)\end{array}$ & $\begin{array}{l}-0.049^{\star \star \star} \\
(0.003)\end{array}$ & $\begin{array}{l}-0.003 \\
(0.003)\end{array}$ & $\begin{array}{l}-0.064^{\star \star \star} \\
(0.003)\end{array}$ & $\begin{array}{l}-0.036^{\star \star \star} \\
(0.003)\end{array}$ & $\begin{array}{c}-0.010^{\star \star \star} \\
(0.003)\end{array}$ \\
\hline $\mathrm{BMI}>2 \mathrm{O} \& \leq 25$ & Ref. & Ref. & Ref. & Ref. & Ref. & Ref. & Ref. & Ref. \\
\hline $\mathrm{BMI}>25 \& \leq 30$ & $\begin{array}{l}-0.074^{\star \star \star} \\
(0.004)\end{array}$ & $\begin{array}{l}-0.072^{\star \star \star} \\
(0.004)\end{array}$ & $\begin{array}{l}-0.056^{\star \star \star} \\
(0.004)\end{array}$ & $\begin{array}{l}-0.041^{\star \star \star} \\
(0.004)\end{array}$ & $\begin{array}{l}-0.033^{\star \star \star} \\
(0.004)\end{array}$ & $\begin{array}{l}0.013^{\star \star *} \\
(0.004)\end{array}$ & $\begin{array}{l}-0.064^{\star \star \star} \\
(0.004)\end{array}$ & $\begin{array}{l}-0.010^{\star *} \\
(0.004)\end{array}$ \\
\hline $\mathrm{BMI}>30$ & $\begin{array}{l}-0.183^{\star \star \star} \\
(0.009)\end{array}$ & $\begin{array}{l}-0.183^{\star \star \star} \\
(0.009)\end{array}$ & $\begin{array}{l}-0.153^{\star \star \star} \\
(0.009)\end{array}$ & $\begin{array}{l}-0.122^{\star \star \star} \\
(0.009)\end{array}$ & $\begin{array}{l}-0.072^{\star \star \star} \\
(0.009)\end{array}$ & $\begin{array}{l}0.001 \\
(0.009)\end{array}$ & $\begin{array}{l}-0.162^{\star \star \star} \\
(0.009)\end{array}$ & $\begin{array}{l}-0.027^{\star \star \star} \\
(0.009)\end{array}$ \\
\hline $\begin{array}{l}\text { Cognitive skill: } \\
\text { Enlistment test score }\end{array}$ & - & - & - & $\begin{array}{l}0.105^{\star \star \star} \\
(0.001)\end{array}$ & - & - & - & $\begin{array}{l}0.069^{\star \star \star} \\
(0.001)\end{array}$ \\
\hline $\begin{array}{l}\text { Non-cognitive skill: } \\
\text { Psychological evaluation }\end{array}$ & - & - & - & - & $\begin{array}{l}0.133^{\star \star \star} \\
(0.001)\end{array}$ & - & - & $\begin{array}{l}0.103^{\star \star \star} \\
(0.002)\end{array}$ \\
\hline $\begin{array}{l}\text { Physical fitness: } \\
\text { Cardiovascular fitness }\end{array}$ & - & - & - & - & - & $\begin{array}{l}0.077^{\star \star \star} \\
(0.001)\end{array}$ & - & $\begin{array}{l}0.023^{\star \star \star} \\
(0.001)\end{array}$ \\
\hline Muscular strength & - & - & - & - & - & - & $\begin{array}{l}0.027^{\star \star \star} \\
(0.001)\end{array}$ & $\begin{array}{l}0.011^{\star \star \star} \\
(0.001)\end{array}$ \\
\hline Age & Yes & Yes & Yes & Yes & Yes & Yes & Yes & Yes \\
\hline Height & No & Yes & Yes & Yes & Yes & Yes & Yes & Yes \\
\hline Parental characteristics & No & No & Yes & Yes & Yes & Yes & Yes & Yes \\
\hline $\begin{array}{l}\text { Reduction (\%) in original } \\
\text { (Model C) obesity penalty }\end{array}$ & & & & 20 & 53 & 100 & -5 & 82 \\
\hline $\mathrm{R} 2$ & 0.01 & 0.02 & 0.03 & 0.04 & 0.05 & 0.04 & 0.03 & 0.06 \\
\hline No of cases & 448,667 & 448,667 & 448,667 & 448,667 & 448,667 & 448,667 & 448,667 & 448,667 \\
\hline
\end{tabular}


Table 4.2. Earnings and BMI. Men 28-38 years old, 2003. Logarithm of annual earnings. Siblings data.

\begin{tabular}{|c|c|c|c|c|c|c|c|c|}
\hline Variable & A & $\mathrm{B}$ & C & $\mathrm{D}$ & $\mathrm{E}$ & $\mathrm{F}$ & G & $\mathrm{H}$ \\
\hline $\mathrm{BM} \leq 20$ : & $\begin{array}{l}-0.044^{\star \star \star} \\
(0.005)\end{array}$ & $\begin{array}{l}-0.025^{\star \star \star} \\
(0.007)\end{array}$ & $\begin{array}{c}-0.026^{\star \star \star} \\
(0.007)\end{array}$ & $\begin{array}{l}-0.023^{\star \star \star} \\
(0.007)\end{array}$ & $\begin{array}{l}-0.003 \\
(0.007)\end{array}$ & $\begin{array}{l}-0.036^{\star \star \star} \\
(0.007)\end{array}$ & $\begin{array}{l}-0.015^{\star \star} \\
(0.007)\end{array}$ & $\begin{array}{l}-0.006 \\
(0.007)\end{array}$ \\
\hline $\mathrm{BM}>20 \& \leq 25$ & Ref. & Ref. & Ref. & Ref. & Ref. & Ref. & Ref. & Ref. \\
\hline $\mathrm{BM}>25 \& \leq 30$ & $\begin{array}{l}-0.073^{\star \star \star} \\
(0.007)\end{array}$ & $\begin{array}{l}-0.040^{\star \star *} \\
(0.010)\end{array}$ & $\begin{array}{c}-0.039^{\star \star \star} \\
(0.010)\end{array}$ & $\begin{array}{l}-0.031^{\star \star *} \\
(0.010)\end{array}$ & $\begin{array}{c}-0.030^{\star \star \star} \\
(0.010)\end{array}$ & $\begin{array}{l}-0.001 \\
(0.010)\end{array}$ & $\begin{array}{c}-0.045^{\star \star \star} \\
(0.010)\end{array}$ & $\begin{array}{l}-0.012 \\
(0.010)\end{array}$ \\
\hline $\mathrm{BM}>30$ & $\begin{array}{l}-0.171^{\star \star \star} \\
(0.016)\end{array}$ & $\begin{array}{l}-0.090^{\star \star \star} \\
(0.021)\end{array}$ & $\begin{array}{l}-0.091^{\star \star *} \\
(0.021)\end{array}$ & $\begin{array}{l}-0.076^{\star \star \star} \\
(0.021)\end{array}$ & $\begin{array}{l}-0.052^{\star \star \star} \\
(0.021)\end{array}$ & $\begin{array}{l}-0.002 \\
(0.021)\end{array}$ & $\begin{array}{l}-0.099^{\star \star \star} \\
(0.021)\end{array}$ & $\begin{array}{l}-0.015 \\
(0.021)\end{array}$ \\
\hline $\begin{array}{l}\text { Cognitive skill: } \\
\text { Enlistment test score }\end{array}$ & - & - & - & $\begin{array}{l}0.099^{\star \star \star} \\
(0.003)\end{array}$ & - & - & - & $\begin{array}{l}0.075^{\star \star \star} \\
(0.003)\end{array}$ \\
\hline $\begin{array}{l}\text { Non-cognitive skill: } \\
\text { Psychological evaluation }\end{array}$ & - & - & - & - & $\begin{array}{l}0.092^{\star \star \star} \\
(0.003)\end{array}$ & - & - & $\begin{array}{c}0.066^{\star * \star} \\
(0.004)\end{array}$ \\
\hline $\begin{array}{l}\text { Physical fitness: } \\
\text { Cardiovascular fitness }\end{array}$ & - & - & - & - & - & $\begin{array}{l}0.050^{\star \star x} \\
(0.003)\end{array}$ & - & $\begin{array}{l}0.023^{\star \star \star} \\
(0.003)\end{array}$ \\
\hline Muscular strength & - & - & - & - & - & - & $\begin{array}{l}0.024^{\star \star \star} \\
(0.003)\end{array}$ & $\begin{array}{l}0.013^{\star \star \star} \\
(0.003)\end{array}$ \\
\hline Age & Yes & Yes & Yes & Yes & Yes & Yes & Yes & Yes \\
\hline Height & No & No & Yes & Yes & Yes & Yes & Yes & Yes \\
\hline $\begin{array}{l}\text { Reduction (\%) in original } \\
\text { (Model C) obesity penalty }\end{array}$ & & & & 16 & 43 & 98 & -9 & 84 \\
\hline Sibling fixed effects & No & Yes & Yes & Yes & Yes & Yes & Yes & Yes \\
\hline $\mathrm{R} 2$ & 0.01 & 0.01 & 0.02 & 0.04 & 0.05 & 0.03 & 0.02 & 0.05 \\
\hline No of cases & 145,193 & 145,193 & 145,193 & 145,193 & 145,193 & 145,193 & 145,193 & 145,193 \\
\hline
\end{tabular}

Notes: This table reports estimates from the (2) regression model: Log Earnings = a + b*BMI_class + c*X + d*Missing info + f + e.

Model A only includes BMI categories and age and is estimated using OLS for the sibling sample. Model B adds siblings fixed effects and Model C

height. Model D adds cognitive skill, Model E non-cognitive skill, while Model F and G add the physical fitness variables. Model H adds all variables. 
Table 4.3. The BMI estimates and different outcome measures. Siblings. Men 28-38 years old, 2003. Logarithm of annual earnings.

\begin{tabular}{|c|c|c|c|c|c|c|}
\hline & (i) & (ii) & (iii) & (iv) & (v) & (vi) \\
\hline \multicolumn{7}{|l|}{ Modell C: } \\
\hline $\mathrm{BM}$ < $20:$ & $\begin{array}{c}-0.026^{\star \star \star} \\
(0.007)\end{array}$ & $\begin{array}{c}-0.024^{\star \star \star} \\
(0.007)\end{array}$ & $\begin{array}{c}-0.017^{\star \star \star} \\
(0.003)\end{array}$ & $\begin{array}{c}-0.018^{\star \star} \\
(0.007)\end{array}$ & $\begin{array}{c}-0.026^{\star \star *} \\
(0.008)\end{array}$ & $\begin{array}{c}-0.028^{\star \star} \\
(0.008)\end{array}$ \\
\hline $\mathrm{BMl}>20 \& \leq 25$ & Ref. & Ref. & Ref. & Ref. & Ref. & Ref. \\
\hline $\mathrm{BMl}>25 \& \leq 30$ & $\begin{array}{c}-0.039^{\star \star \star} \\
(0.010)\end{array}$ & $\begin{array}{c}-0.038^{\star \star \star} \\
(0.010)\end{array}$ & $\begin{array}{c}-0.017^{\star \star \star} \\
(0.005)\end{array}$ & $\begin{array}{c}-0.026^{\star \star} \\
(0.010)\end{array}$ & $\begin{array}{c}-0.041^{\star \star \star} \\
(0.011)\end{array}$ & $\begin{array}{c}-0.050^{\star \star \star} \\
(0.012)\end{array}$ \\
\hline $\mathrm{BMI}>30$ & $\begin{array}{c}-0.091^{\star \star \star} \\
(0.021)\end{array}$ & $\begin{array}{c}-0.091^{\star \star \star} \\
(0.020)\end{array}$ & $\begin{array}{c}-0.048^{\star \star \star} \\
(0.010)\end{array}$ & $\begin{array}{c}-0.111^{\star \star \star} \\
(0.022)\end{array}$ & $\begin{array}{c}-0.113^{\star \star \star} \\
(0.024)\end{array}$ & $\begin{array}{c}-0.090^{\star \star} \\
(0.027)\end{array}$ \\
\hline \multicolumn{7}{|l|}{ Modell H: } \\
\hline $\mathrm{BM}<<2 \mathrm{O}$ & $\begin{array}{l}-0.006 \\
(0.007)\end{array}$ & $\begin{array}{l}-0.005 \\
(0.007)\end{array}$ & $\begin{array}{l}-0.007 \\
(0.003)\end{array}$ & $\begin{array}{c}0.002 \\
(0.008)\end{array}$ & $\begin{array}{l}-0.007 \\
(0.008)\end{array}$ & $\begin{array}{l}-0.005 \\
(0.008)\end{array}$ \\
\hline $\mathrm{BM}>20 \quad \& \leq 25$ & Ref. & Ref. & Ref. & Ref. & Ref. & Ref. \\
\hline $\mathrm{BM}>25 \& \leq 30$ & $\begin{array}{l}-0.012 \\
(0.010)\end{array}$ & $\begin{array}{l}-0.012 \\
(0.010)\end{array}$ & $\begin{array}{c}0.001 \\
(0.005)\end{array}$ & $\begin{array}{c}0.001 \\
(0.011)\end{array}$ & $\begin{array}{l}-0.016 \\
(0.011)\end{array}$ & $\begin{array}{l}-0.020 \\
(0.013)\end{array}$ \\
\hline $\mathrm{BMI}>30$ & $\begin{array}{l}-0.015 \\
(0.021)\end{array}$ & $\begin{array}{l}-0.017 \\
(0.021)\end{array}$ & $\begin{array}{l}-0.001 \\
(0.010)\end{array}$ & $\begin{array}{l}-0.034 \\
(0.023)\end{array}$ & $\begin{array}{l}-0.039 \\
(0.025)\end{array}$ & $\begin{array}{l}-0.010 \\
(0.027)\end{array}$ \\
\hline Sibling fixed effects & Yes & Yes & Yes & Yes & Yes & Yes \\
\hline No of cases & 145,193 & 145,193 & 132,881 & 143,507 & 131,047 & 123,512 \\
\hline
\end{tabular}

Notes: Column (i) is the BMI estimates from Model C in Table 4.2, while Column (ii) and (iii) shows the BMI estimates for those with top coded earnings and earnings above 100' SEK, respectively. Column (iv) and (v) gives the BMI estimates when excluding earnings subsidies and enlistment "fakers", respectively. Finally, Column (vi) gives the BMI estimates when especially strong individuals are withdrawn from the sample, that is, those 1 standard deviation above average hand grip strength. It has been proposed that BMI might be a bad measure for individuals with a great muscular mass. 


\section{Appendix:}

Table A1. Variable List

\begin{tabular}{|c|c|}
\hline Variable & Definition of the variable \\
\hline BMI & $\begin{array}{l}\text { Measured at age } 18 \text { when enlisting. Calculated as a persons weight in } \mathrm{kg} \text { divided by the square } \\
\text { of his length in meters. }\end{array}$ \\
\hline Logarithm annual earnings & Annual earnings in 2003 from work or self-employment. Including subsidies. \\
\hline Age & In 2003. 28-38 years old. \\
\hline \multicolumn{2}{|l|}{ Parental characteristics: } \\
\hline Fathers' (log) earnings & Annual earnings in 1980 from work or self-employment \\
\hline Mothers' (log) earnings & Annual earnings in 1980 from work or self-employment \\
\hline Fathers years of schooling & Years of schooling, taking values from 9-18. Measured in 1999. \\
\hline Mothers years of schooling & Years of schooling, taking values from 9-18. Measured in 1999. \\
\hline Cognitive skill: & Measured at age 18 when enlisting. The enlistment test score on a scale 1-9. \\
\hline Non-cognitive skill: & Measured at age 18 when enlisting. Evaluated by a psychologist, on a scale 1-9. \\
\hline $\begin{array}{l}\text { Physical fitness: } \\
\text { Cardiovascular fitness }\end{array}$ & $\begin{array}{l}\text { Measured at age } 18 \text { when enlisting. During a } 5-10 \text { minute exercise it was measured the highest } \\
\text { watts attained when riding on a stationary bike. This measure is then divided by the individuals } \\
\text { weight in kilograms. }\end{array}$ \\
\hline Muscular strength & Measured at age 18 when enlisting. Handgrip strength of strongest hand. \\
\hline Height & Measured at age 18 when enlisting. \\
\hline \multicolumn{2}{|l|}{ Missing information on: } \\
\hline Fathers' (log) earnings & $\begin{array}{l}\text { Takes a } 1 \text { if missing information on fathers' log earnings and zero otherwise. If missing the } \\
\text { mean of fathers' log earnings is imputed. }\end{array}$ \\
\hline Mothers' (log) earnings & $\begin{array}{l}\text { Takes a } 1 \text { if missing information on mothers' log earnings and zero otherwise. If missing the } \\
\text { mean of mothers' log earnings is imputed. }\end{array}$ \\
\hline Fathers years of schooling & $\begin{array}{l}\text { Takes a } 1 \text { if missing information on fathers years of schooling and zero otherwise. If missing the } \\
\text { mean of fathers years of schooling is imputed. }\end{array}$ \\
\hline Mothers years of schooling & $\begin{array}{l}\text { Takes a } 1 \text { if missing information on mothers' years of schooling and zero otherwise. If missing } \\
\text { the mean of mothers' years of schooling is imputed. }\end{array}$ \\
\hline $\begin{array}{l}\text { Maximum watts on stationary } \\
\text { bike }\end{array}$ & $\begin{array}{l}\text { Takes a } 1 \text { if missing information on maximum watts on stationary bike and zero otherwise. If } \\
\text { missing the mean of maximum watts on stationary bike is imputed. }\end{array}$ \\
\hline Handgrip strength & $\begin{array}{l}\text { Takes a } 1 \text { if missing information on handgrip strength and zero otherwise. If missing the mean of } \\
\text { handgrip strength is imputed. }\end{array}$ \\
\hline
\end{tabular}

